JOURNAL OF SECURITY AND SUSTAINABILITY ISSUES

ISSN 2029-7017 print/ISSN 2029-7025 online

2019 March Volume 8 Number 3

http://doi.org/10.9770/jssi.2019.8.3(1)

Scopus

\title{
BARRY BUZAN'S SECURITIZATION THEORY AND THE CASE OF IRAQI KURDISH MILITARY ACTION AGAINST ISIS IN 2014
}

\author{
János Besenyő \\ HDF General Staff Scientific Research Centre, H-1885 Budapest, Pf.25, Hungary \\ E-mail: besenyo.janos@gmail.com
}

Received 11 March 2018; accepted 20 February 201; published 30 March 2019

\begin{abstract}
Barry Buzan's thought has shaped constructivism and International Security Studies since the 1990s. In this paper, it is argued that ISS does insufficient justice to the case of the Iraqi Kurdish military counterattacks and wider societal mobilization against ISIS. The paper introduces the concepts of spontaneous and semi-spontaneous securitization, where the referent object of securitization is not the nation state or even the Kurdistan Region but the more traditionally defined community and its individual members, plus religiously or ethnically defined groups that are under the protection of the regionally dominant identity community. Worryingly, in Sunni Arab areas such as Mosul, insurrection and semi-spontaneous securitization has been an aspect to how ISIS captured that city. Further theoretical problems such as the securitization of immigration in Buzan's theoretical framework, are exposed and applied to the case of ISIS and Iraqi Kurdistan. Research for this article took place during on the field visits to Erbil and the KRI in 2016 by the author and his team of HDF General Staff Scientific Research Centre.
\end{abstract}

Keywords: ISIS; Kurdistan, Erbil siege, Kurdistan security, Securitization Theory, securitization of immigration

Reference to this paper should be made as follows: Besenyő, J. 2019. Barry Buzan's Securitization Theory and the case of Iraqi Kurdish military action against ISIS in 2014, Journal of Security and Sustainability Issues 8(3): 295-306.

http://doi.org/10.9770/jssi.2019.8.3(1)

JEL. Classification:

\section{Introduction}

In the contemporary world security enhancement has become precondition of sustainable development; various security facts are being continuously revealed and analyzed in scientific literature (e.g. Limba et al. 2017; Mikhaylov et al. 2018; Tvaronavičienè 2018; Lisin et al. 2018; Eddelani et al. 2019). International Security Studies (ISS) is among the most respected theoretical frameworks for security today, arguably surpassing even the popularity of the neorealist school, or 'national security' based classical realist schools, especially in the UK and in much of continental Europe. Barry Buzan's and Ole Waever's thought has shaped constructivism in International Relations, and specifically ISS in definitive ways since the latter's inception in the 1990s. In this paper, it is argued that mainstream ISS, and specifically also securitization theory as expounded by Buzan, Ole Waever and Jacobus Hubertus "Jaap" de Wilde, in their current form do insufficient justice to the case of the Iraqi Kurdish military counterattacks and wider societal mobilization against ISIS, and to other, related cases of insurgency in the region. In Buzan's theory of securitization, which focuses on institutional securitization and not ad hoc securitization (a category he mentions but does not elaborate on), the enunciator/actor who securitizes a given political, economic, social, or religious issue through a speech act, always has the choice of avoiding 'securitization through communicative action': a choice that is distinct from the securitizing speech act and which keeps the given issue within the realm of the political. Through my paper, I intend to prove that in the case of Iraqi Kurdish Peshmerga and their political representatives in and around Erbil in the late summer and 
early autumn of 2014, there presented itself no such choice, and that as a result, we may refer to Iraqi Kurdish Peshmerga actions as guided by traditional concepts of (ethno-) national survival (rather than the constructivist notion of securitization); and without any fear of philosophical naivety. We will invoke historicity in the form of historical experience and precedent to aid us in our understanding of the forces at work here. On a more general level, this paper intends to prove also that Buzan's constructivist concept of securitization, while it devotes a lot of attention to competing notions of group self-definitions, actually ignores the problematique that is presented by the imminence, or fact, of actual physical annihilation of bodies of humans, whose groups are at liberty to self-define as individuals or collectives - thus appears the historicity of collective experience as it transcends mere media projections, manipulations, and propaganda. Thus incorporating traditional concepts and historicity into a Buzanian theoretical framework in a more nuanced way, I propose the novel categories of spontaneous and semi-spontaneous securitization, as a corrective to the theory's contemporary and modern, statist bias.

\section{Historicity: nation, clan, and historical experience}

Even in the sphere of thought that we might suspect to be farthest from acquiescing to the reality of communal or (ethno-) national historical experience, such as Marxism with its penchant for internationalism, multiculturalism and the global horizon, we find that in its best thinkers such as Gramsci, the historicity of communal experience and the centrality of national self-determination as an inescapable stage of development, are posited (Forman 1998). For thinkers on the right, the ethnic and pre-modern determinants of modern nationalisms are, perhaps predictably, not only admitted grudgingly, but celebrated (such as the intellectually very resourceful Azar Gat in 2012) (Gat 2012). That said, even those Marxist theoreticians of nations and nationalism, against whom Azar Gat railed (a well known example would be Eric Hobsbawm), on account of their severing modern political nations (as artificial constructs) from their pre-modern extraction (and who thus constitute the constructivist, as opposed to the primordialist school of Nationalism Studies) (Hobsbwam 1992): even they do not dream of doing away with the centrality of historical experience for communities, with the historicity of experience, indeed, with History (understood in the former's case within the framework of historical materialism) (Mayer 2016).

Besides constructivist International Security Studies thinkers and IR theorists, the group of thinkers who are most ready to neglect the reality of History and its crucial (indeed, sometimes even calculable) effects on individuals and groups, are post-modernist, post-structuralist thinkers and literary theorists, among them such towering figures as Gayatri Chakravorty Spivak. One finds it commendable that (certain types of) Marxisms allow for speculative theorising, but one may well find it disturbing when theorising acquires qualities that are arguably ahistorical. When Gayatri Spivak intends to disconnect the appearance of modern nations and modern nationalisms from their chronological point of origin, the late $18^{\text {th }}$ century, and offers vague and mystical definitions instead ("I do not locate the nation in the $18^{\text {th }}$ century... I connect it to reproductive heteronormativity") (Spivak 2010), one stands puzzled. While the reader keeps wondering whether Spivak means by this simply that women give birth and birth defines one's nation (the conservative primordialist view par excellence) or she has some other goal in mind, one still finds this a reason to mourn the disappearance of vital historical sensitivity in some influential Marxian/post-structuralist critical theory.

It is admissible then to find the security theorist Barry Buzan more candid than Spivak in that he openly shuts out any Marxian inferences from his work whilst attempting to bury concepts of historicity (and even when it comes to his collaboration with feminist thinker Hansen, he opts for a version of critical theory that does not even pretend to offer Marxian tools of analysis.) (Buzan \& Lawson 2015; Buzan \& Hansen 2009). Naturally, there will be a price to pay even for this (not in the sense of losing articles of positivist "truth" but in the sense of loss through a negation of theoretical engagement). I will argue how the price that Buzan will pay for the lack of engagement with radical aspects of critical theory is blind spots of a normative nature, especially in his problematic securitizing of immigration: as relevant for Europe as for the Kurdistan Regional Government today.

Finally, this article introduces the concepts of spontaneous and semi-spontaneous securitization, where the referent object of securitization is not the Western liberal democratic nation state or even the Kurdistan Region but the more traditionally defined community and its individual members, plus religiously or ethnically defined groups that were under the protection of the (regionally) dominant identity community. Semi-spontaneous 
(civilian) insurrection, coordinated or not by Peshmerga commanders on the ground, is a historically relevant phenomenon in the Kurdish case, which (luckily for the region and for all adversaries of ISIS) might have played out to beneficial effect in protecting Erbil Governorate from an ISIS attack in the second half of 2014. A similar case of semi-spontaneous securitization happened in late 2016, when Kirkuk experienced a sudden ISIS attack, which was repelled by coordinated Peshmerga action along with (significantly for our argument here) semi-spontaneous insurrectionary action by private individuals. Worryingly, in Sunni Arab areas such as Mosul, insurrection and semi-spontaneous securitization was an aspect to how ISIS captured that city.

\section{The need for theory in the case of Iraqi Kurdish insurrection against ISIS in 2014}

There is nothing unusual about people running away from danger, and as everywhere else, this did happen in Erbil in the late summer and early autumn of 2014, when ISIS approached the city's environs and when it credibly threatened to overtake both the city's airport and also the city itself. Members of the city's thriving expat community, oil industry experts and NGO workers, the minority communities of Yezidis, Christians, Alawites, along with the city's majority Sunni Muslim Kurdish population, were on high alert. With the airport closed, many Westerners simply packed all their belongings to their cars and drove off towards the Turkish border.

As Susan Strange puts it, we do not need theory when people run out of a burning building: self-preservation requires no elaborate explanations (Strange 1988). We do need theory however, if and when people run into a burning building.

Given ISIS's track record by the late summer of 2014, joining the Peshmerga effort against ISIS on the frontline was akin to running into a burning building. More than that, at that juncture, not only Peshmerga fighters (who were, after all, on the Kurdistan Regional Government's payroll) joined the effort. It has been noted extensively how groups of students, young people with their cousins, young people individually and in small groups, gathered their light arms, sat in their car, and left off for the frontline with or without prior Peshmerga training in the hinterland. Foreign volunteers also joined in from various Western countries, but naturally, logistics in their case was not as simple (although it did require as much courage on the individual level) (Misri 2014; Dalshad 2014).

\section{Applying theory to the case}

Now let us look at how such behavior concurs with securitization theory, specifically of the Copenhagen School of IR that of the founding fathers of International Security Studies. International Security Studies is among the most respected theoretical frameworks for security today, arguably surpassing even the popularity of the neorealist school, or 'national security' based classical realist schools, especially in the UK and in much of continental Europe.

In Buzan's theory of securitization, in the case of institutionalized securitization, the enunciator/actor who securitizes a given military, political, economic, social, cultural, ecological, or religious issue always has the choice of avoiding 'securitization through communicative action': a choice that is distinct from the securitizing speech act; keeping the issue at hand in the regular sphere of regular politics. I argue here that no such choice presented itself for Kurdish political decision makers and (the overwhelming majority of) able bodied men and women in the late summer days of 2014. Although there existed some ethnic Kurdish supporters of ISIS both within Erbil and around it; they acted against the overwhelming majority of their identity community's mainstream opinion. The key to understanding here is familiarity with the track record of ISIS prior to August 2014.

ISIS ideologically is an offshoot of the Wahabiyya (House of Commons Library 2015), where the Shia, Sufis, or secular Muslims are not considered Muslims at all, and where dhimmis (Jews, Christians, Zoroastrians) are not protected and their rites and places of worship not tolerated (Cockburn 2015). To this ISIS added a cult of martyrdom, which is actually Shia in origin (Hezbollah, early 1980s) (!). ISIS uses suicide bombers in battle, a tactical innovation. In fact many ISIS fighters "went to Iraq and Syria with the express intention of becoming martyrs." (Cockburn 2015). Not only 'polytheists' (Christians) were assaulted and forced to flee ISIS's advances, 
but so were Yazidis (Zoroastrians in origin) in early August 2014 (Cockburn 2015). Moderate Sunni (who are called 'apostates' in ISIS parlance) are also deemed enemies and moderate Sunni villages were destroyed to the ground. ISIS fighters are, and were, prior to the seizure of Mosul, "experts in fear." (Cockburn 2015).

From 2005 to 2009, Abu Bakr Al Baghdadi, was the future "caliph" of ISIS, was a prisoner of the Americans, for taking part in the Sunni uprising (Cockburn 2015). He became, in the summer of 2010, the leader of al-Qaeda in Iraq (Cockburn 2015). When the Syrian Uprising destabilized the region from 2011, the ground was prepared for the appearance of an organization that put al-Qaeda to shame with its ferocity. ISIS in 2013 prepared an attack on the Abu Ghraib prison, and went on (in January 2014) to take over Falluja (another famous and symbolic spot). In March, it paraded through the city. Cockburn puts it thus: "Merciless in enforcing compliance with its own exclusive and sectarian variant of Islam, ISIS killed or forced to flee all whom it targeted as 'apostates' or 'polytheists' (...). Its leaders were the products of a decade of war in Iraq and Syria, and deliberate martyrdom through suicide bombings was a central and effective feature of their military tactics." (Cockburn 2015).

When it comes to tactics and war materiel, ISIS proved both focused and lucky. ISIS became extremely wellarmed. It captured Humvees from the Iraqi Army, and "ISIS members say they are always pleased when sophisticated weapons are sent to anti-Assad groups of any kind, because they can always get the arms off them by threat of force or cash payments." (Cockburn 2015). Add to this the possibility of active help by private actors in Saudi Arabia, the UAE and other Gulf states.

As a result, in the battle of Mosul, on June 6, 2014, a 1300-strong force of ISIS won against a nominal 60,000-strong force including the Iraqi Army and the federal and local police - an almost incredible achievement from a tactical point of view (Cockburn 2015). Not even the above factors, nor the fact that by then, ISIS was "intoxicated by its own triumphs" (Cockburn 2015) could account for such a victory.

In fact, the key lies in the Sunni Arab popular reaction to ISIS and its advance. ISIS might have been tactically very apt (as in the case of diversions right before the battle of Mosul) (Cockburn 2015) but the key factor was that ISIS had had a continuous presence in the city since 2013, it was busy racketeering ever since then, and that it was viewed as a lesser evil by many Sunnis, when they compared them to Nuri al-Maliki's Shia-dominated Iraqi Army, or the Shia militias. In fact, Cockburn asserts that "The fall of Mosul was the result of a popular uprising as well as a military assault." (Cockburn 2015) as Army barracks were invaded by crowds of civilians even prior to the full takeover of the city by ISIS. Thus, we may see that 'popular uprising,' insurrection, and what I call in this paper 'spontaneous securitization' and 'semi-spontaneous securitization,' has been relevant not only to Kurdish community reactions to ISIS's attack, but also to ISIS itself, and its relationship to its core identity community in Iraq (which is Sunni Arabs).

ISIS controlled territories exist in a space where nearly every aspect of life is subject to extreme interpretations of the Islamic religion, based originally on the Wahabiyya's Salafism but reaching new lows in the dehumanization of women, non-Muslims, Sufis, Shias, etc. Whether it is forbidden to clap or for women to wear bras, smoke cigarettes (discouraged), watching football (that can get youngsters decapitated). In its West African affiliate Boko Haram, ISIS even subscribed to the "flat earth conspiracy." Most of human knowledge, the past, culture, religion, customs, literature, music (banned under Taliban and also under ISIS) is securitized. ISIS held areas thus exist in a space where nearly everything is securitized, where there is no default sphere of "the political." On $14^{\text {th }}$ February, 2017, ISIS warned inhabitants of Mosul not to wear the color red because doing so would amount to celebrating Valentine's Day (and as such, would bring on the perpetrator the death penalty) (!).

Utilizing to full extent, all possible modern means of social media, digital media, film, and PR, ISIS also makes a virtue of its callous brutality. (Besenyő \& Prantner \& Speidl \& Vogel 2016) Its interpretation of who falls under the category of dhimmi in itself is extreme, but its observable practice on religious minorities is jizye as extortion, and punishment amounting to genocide. In both the Syrian and the Iraqi context, partly because of the secular movements that Kurds have actively supported (PKK, PYK, and partly PUK) and the Sufi orientation of its more conservative leaders (PDK), the Kurdish community has been labelled 'kafir' by al-Baghdadi, and treated accordingly. 
Neither may we say that a given 'speech act' by President Barzani, Prime Minister Barzani, or Peshmerga generals and commanders, would have performed some kind of unitary, centralized, securitization in the manner of Waever, de Wilde and Buzan for volunteers who just drove to the frontline with their guns.

In The Evolution of International Security Studies, securitization is that which "frames an issue as a special kind of politics, or above politics" where existential threat is the key (Buzan \& Hansen 2009). For the authors, "securitization is a self-referential practice" thus it is in practice "that the issue becomes a security issue" and the threat is not necessarily real in any sense. What "does" securitization is the securitizing discourse itself, which, together with the receptive reaction of the audience, acts as a combined self-referential practice (thus securitization is never completely enforced). It is predicated on the inter-subjectively perceived existential threat to a given identity community, territory, or values, thus starting any kind of emergency action. Security removes this emergency action from the realm of the political and negotiable. Security of course is clearly not the absence of threats in Buzan's framework, but rather the act of pursuing such a state through a removal of (inter-subjectively perceived) existential threats. For Buzan, there is simply no possible case of an objective threat that requires no further explanation and herein lies a key aspect to his constructivism. I argue that this is an ahistorical view as it takes away the dynamic of not only the historicity of certain group conflicts (which is very relevant to the Kurdish - Sunni Arab relationship), historical experience of actors on the ground, chronological aspects (as just months before the ISIS advance on Erbil, Mosul was attacked with terrible efficiency, and showed startled populations the viciousness of its kind of rule). Thus Buzan simply ignores the possibility that given a certain existential threat, securitization may not need a securitizing speech act by enunciators or political actors (especially under the fluid conditions of the then rather unstable federal structure of Iraq), but communities, large and small kinship groups, individual actors (including expatriate Kurds and non-Kurds from as far as Canada) may see objectively, the nature of the existential threat to their survival or the survival of Iraqi Kurdish autonomy and decide to take security in their own hands, and join an attack on ISIS's frontline with or without Peshmerga training, when their city is clearly in danger.

In The Evolution of International Security Studies, Buzan stresses that for ISS, the key referent object is the state, with its exclusive authority, clearly defined borders (as opposed to frontiers), sovereign, territorial, and secular. Even according to Buzan, it is very reasonable to challenge the state as the primary referent object of security when states are too weak or even failed to provide security (he singles out Somalia, Afghanistan, Haiti, and the Democratic Republic of the Congo). Iraq may or may not be considered a failed state or a state that is failing, but this is not the only reason why we may question whether the federal state, or even its Kurdistan Region, may be thought of as the key referent object of security. After all, it is de rigueur to distinguish between the official borders of the KRG administered area and its actual frontiers (which are less easily defined - the famous article 140 of the Iraqi Constitution is a case in the point); authority is shared between parties on a regional (intra-KRG) basis, full sovereignty has not been achieved, the principle of territoriality is not always stronger than ethnic ties and concepts of protection; and lastly, while the Kurdistan Region chooses not to implement most of Baghdad's sharia inspired legislation, the Iraqi constitution is explicitly not secular (it posits Iraq as an Islamic state).

I claim that although in the case of the ISIS attack on Iraqi Kurdistan and Erbil Governorate in August/ September 2014, the referent object of security was only very partially the state or its federal constituent the KRG. Rather, the referent object of security, and the entire focus of securitization went deeper and further than usual securitization (which is in itself, by definition, extraordinary as it moves action out of the sphere of the political), in this case reaching individuals, small groups, traditional clan and kinship structures within the ethnic Kurdish relative majority and within minority communities of 'protected' Christians, and Yezidis. As securitization reached the individual, the family and the clan as its referent object, it also acted in a way that is different in some ways from notions that Buzan and Waever posit as general. On p. 34, in The Evolution of Security Studies, Buzan writes that "The process through which threats are identified and given meaning is better understood through an analysis of identity building and institutional transformation that does not lend itself to causality or quantification." (Buzan \& Hansen 2009). While it is easy to agree with him that quantification would be the wrong approach when it comes to securitization, and that the process through which threats are identified and given meaning is better understood through an analysis of identity building," in the given case the transformation is only partially institutional; and we must take into account a less-than- 
centralized way of securitization, really the devolution of securitization down to the individual, what amounted really, to semi-spontaneous securitization (semi-spontaneous because attempts at coordinating it, in this case, were actually still made). Whilst more traditional securitizing processes were obviously happening (chains of command, originating in the top KRG leadership) through uttering words of securitization, identified threats and performed the Buzanian/Waeverian speech act, the sheer threat to individuals, the chronological connection which lent individuals the knowledge of how ISIS treated its perceived enemies prior to its attack on Erbil, and knowledge of atrocities happening simultaneously with Erbil (especially in Kobani, Northern Syria), pushed individuals to securitize their own (and their families') individual survival, and decided to (with or without any training from Peshmerga commanders) grab their family held assault rifles and take off by private vehicle to the war frontier to confront ISIS; whereby securitizing their own bodies and often lives.

The military efficacy of such securitization is, and has historically been, not clear. Insurrectio, "the insurrection of warriors" was part of the traditional 'law of the land' in places as varied as historical Hungary and semiOttoman vassal Kurdistan. Incorporating and sometimes newly training foreign fighters must have been a draw on Kurdish Peshmerga resources, and this could have contributed to the (apparently) incomplete incorporation of volunteers within Peshmerga units. However, contrary to Buzan's framework, this instance of insurrection, where the state lost (some of) its monopoly on being a referent object of security, did still not bring into operation any kind of Hobbesian situation. On the contrary, the historically informed nature of insurrection in Kurdish society provided an example of how traditional structures may contribute to centrally coordinated action. What might have been lost in military efficacy may be gained as heroic example and role model action for Kurdistan.

We may say that in the case of Kurdish action against ISIS in 2014, the extraordinary procedures of securitization themselves were superseded by individual and small group-action that was akin to certain historical forms of insurrection. Forces that were not Peshmerga members, could not possibly be 'instrumentalized' in neat and organized processes of even a clan based military force but were acting in a way in which individuals made choices that amounted to (a very high probability of) voluntary self-sacrifice.

On a general level, this paper intends to prove also that Buzan's constructivist concept of securitization, while it devotes a lot of attention to competing notions of group self-definitions, actually ignores the problematique that is presented by the imminence, fact, or credible threat of actual physical annihilation of bodies of humans, whose groups are at liberty to at all self-define as individuals or collectives. The paper introduced the concepts of spontaneous and semi-spontaneous securitization, where the referent object of securitization is not the Western liberal democratic nation state or even the Kurdistan Region as a federal entity of Iraq but the more traditionally defined community and its members (individuals who are members of that community), plus religiously or ethnically defined groups that were under the protection of the (regionally) dominant identity community. Semispontaneous (civilian) insurrection, coordinated or not by Peshmerga commanders on the ground, is a historically relevant phenomenon in the Kurdish case, which (luckily for the region and for all adversaries of ISIS) played out to beneficial effect in protecting Erbil Governorate from an ISIS attack in the second half of 2014; and to the same (uncontestedly beneficial) effect when in late 2016, ISIS demonstrated its ability to strike in Kirkuk. Negative examples of insurrection included the attacks on the barracks in Mosul by Sunni Arabs prior to its full takeover by ISIS. Insurrection, that old "feudal" "insurrectio," is thus not the 'war of all against all': on the contrary, it is a living, albeit historical, form of fighting wars with some relevance in today's Middle East.

\section{Insurrectio within and near the Ottoman sphere}

As demonstrated by Ottomanist scholarship since the 1970s, uprisings and local insurrections were as inherent in the very modus operandi of the Ottoman state as the millet system (Inalcik 1973; Howard 2017), not only in the principalities and other peripheral regions but also in the Anatolian core. Although the Ottoman Kurdish political situation has been likened to the millet system, it was in fact different as Kurdish kings and rulers were not devsirme officials but held their positions in hereditary, some may say feudal, fashion (Ottomans relied mostly on local and hereditary rulers in Kurdistan) (McDowall 1996). The prerogative of the "free warrior" has oft been insurrection. An example of this on the North-Eastern periphery of the Empire was the case of historical Hungary (extant in exile in the Pressburg centred Kingdom of Hungary but a state, the majority 
of which fell as vilayets under the core empire, while other parts such as Transylvania functioned as vassal principalities to the Porte); the refugee nobles of the North kept the legal framework of "insurrectio" as a right and privilege (Agoston 1992).

Kurdish insurrections of the Ottoman centuries have maintained a less legalistic, albeit as relevant standing as their Hungarian counterparts'. Technically, it might ostensibly be safer to refer to tribalism in the Kurdish case (with the addition of aghas and shaiks) than to feudalism (as in the case of the Jaf) (McDowall 1996). As McDowall points out, this in itself is not unproblematic as his classic passage demonstrates:

"The difficulty in discussing Kurdish tribal culture is that tribes are not easy to define since their size, structure and internal organization can vary from place to place and from epoch to epoch. The imprecision implicit in the term 'tribe' is evident from the various words used by Kurds in different parts of Kurdistan, drawn from Arabic, Persian and Turkish, as well as Kurdish, to denote a tribal group: il, ashira, qabila, taifa, tira, oba, hawz and so forth. (...) Very broadly, these terms range from tribal confederation down to clan, sept or section, and to a tented encampment of probably about twenty tents. The actual form taken by a tribal group may depend upon internal factors, such as the personality of its leaders, economic or kin relations with tribal or non-tribal neighbors, and upon external factors“ (McDowall 1996).

McDowall follows in his classic discussion of issues of Kurdish ethnicity and social organization thus: "Other peasant Kurds had no connection with tribes, (...) they lived in conditions of direct landlord-peasant relations (...). Landlords often controlled the essential of life: land, water, livestock and equipment, seed, and labour itself, a situation still true in parts of Kurdistan in the end of the 1970s. Peasants were often unable to move at will. As recently as the 1960s an Iranian Kurdish peasant had to obtain permission from the landlord or his agent to leave the village." (McDowall 1996).

\section{Feudalism: a contested social formation, and its relevance for past insurrections}

Although the term 'feudalism' became a point of contention between Stalin himself and what he termed 'Marxist heterodoxies' in the 1920s-1930s, and any mention of 'feudalism outside Europe' tended to carry a Stalinist connotation since the 1960s-1970s when champions of the "Asiatic mode of production" successfully made this an article of faith for the de-Stalinization of historiography and history in both the Western academe and in Eastern Europe. Such an influence of politics over theory could be as limiting for historical analysis as Stalinism itself however (Sawer 1977/2013; Dunn 2012). Although Stalin was obviously guilty of millions of crimes, and administratively ordering the "correct" interpretation of Marxian social formations was definitely one of them, our analysis should not carry on, however unintentionally, this kind of limitation within or without the confines of Marxist analysis. The notion that feudal social organization could and did happen outside Europe is not in any way more Stalinist than insisting that language has an aspect that transcends class (a view that Stalin also chose to sponsor). McDowall avoids using the term feudalism in his generalized introduction but makes us understand nonetheless that if we want to utilize the concept of tribe with any descriptive power, then we may do the same with the concept of feudalism. If we stick to the structuralist notion that a warrior whose livelihood and military role are both supported by his peasants, we arrive at the concept of feudal relationships even when it comes to the concept of insurrection (as separate from a peasant uprising) (Mayer 2018). A separate but comparable group of people were "the warrior class, living by fighting in time of war and by stockbreeding in peace." (McDowall 1996). Later when discussing the system that was formed after the battle of Chaldiran, McDowall openly (and bravely) endorses the idea that by setting up hereditary amirates in Kurdistan, Ottomans "created a quasi-feudal system," (McDowall 1996) in which "the ruling class lived in the saddle." (...) "The governing principle underlying all arrangements was that where Kurdish tribes maintained good order, provided troops when necessary, and defended the border regions (...), they would be allowed a measure of freedom enjoyed virtually nowhere else in the empire." (McDowall 1996). Of course, David McDowall CBE, a recipient of the Most Excellent Order of the British Empire and a historian, may worry about using the term 'feudalism' less than most academics whose leftist leanings might make them vulnerable to inter-Marxian ideological attack (Mayer 2018). 
The concept of feudalism is not analytically salient in most major works on Kurdish history and politics in an explicit way. Denise Natali in The Kurdish Quasi-State speaks of the "culture of dependency," and explains especially the financial aspect of traditional societies thus: "The Kurdish cash-bazaar economy still had no banking system to finance economic projects or supply loans (...). Many depended upon the traditional hawlana system for loans for loans or turned to leading families or the parties as sources of financing, reinforcing the role of wasta in determining the allocation and distribution of resources" (Natali 2010) - pretty much describing the status of towns under feudalism in general. David Romano in The Kurdish Nationalist Movement: Opportunity, Mobilization, and Identity makes use of the concept of 'tribal identity' and nascent nationalism but does not discuss feudalism (Romano 2016). Neither does Michael M. Gunther in his Historical Dictionary of the Kurds (Gunther 2014). Mohammed M. A. Ahmed, in Iraqi Kurds and Nation Building, focuses on the role of the family in his chapter on Kurdish leadership style (Mohamed Ahmed 2012). A courageous exception to analytical disengagement with the problematique of feudalism in Kurdish history is found (apart from McDowall's synthesis) in Ofra Bengio's edited volume Kurdish Awakening: Nation Building in a Fragmented Homeland, where contrary to contributors such as Eli Amarilyo (who only mention tribalism and nationalism) (Amailyo 2014), Michael Eppel, when discussing Shaikh Ubaydullah, explains that the latter's "motivations were traditional, tribal, and feudal," (Eppel 2014) and talks of "tribal-feudal Kurdish dynasties." (Eppel 2014). When discussing the dissolution the Kurdish emirates (amirates) in the $18^{\text {th }}$ century, he concludes thus: "The vacuum resulting from the elimination of the emirates created conditions for s strengthening of tribal and clannish solidarities and for raising the status of Sufi shayks (...) and the last remnants of a clannish-tribal aristocracy." (Eppel 2014). What we see in Eppel is thus the strengthening of feudal relations with the disappearance of the larger amirs and amirates.

Although already from the battle of Chaldiran onwards, we see a relative lull in the intensity of Kurdish insurrections, from the early $19^{\text {th }}$ century up to (arguably) this very day (2017), we are witnessing all the more of them in most formerly Ottoman regions of Kurdistan. Already in the $18^{\text {th }}$ century, derebeys (valley lords) turned their fiefdoms hereditary (McDowall 1996), and in the early $19^{\text {th }}$ century, the central government could not avoid recognizing formally that the Sultan shared "his once absolute power with local potentates, among them the Kurdish chiefs, who derived their power from local sources." (McDowall 1996). With Mahmud II, the Empire went on a counteroffensive, deposing derebeys and trying to eliminate the Kurdish hereditary kingdoms (amirates). First fell Mir Muhammad (McDowall 1996), then Badr Khan Beg (McDowall 1996), until certain Sufi tariqas rose to prominence due especially to the protection that they offered to former oppressed members of kinship structures, religious and spiritual credibility, and conflict resolution skills (such as the Barzanis) (McDowall 1996). With Shaik Ubaid Alla of Nihri, such insurrections acquired a distinct Kurdish national and nationalist character in the 1880s, which they maintained ever since, as in the case of the Barzani Uprising (1908). The freedom associated with traditional uprisings and insurrections may cause rifts and can hinder unified action in any given historical epoch. Indeed, as McDowall puts it, "lack of coordination remained the Kurds' Achilles heel." (McDowall 1996). Historical notions such as insurrection, naturally, do not remain intact in ethnic or national communities in the vein of psychic residue or some kind of historical ballast (Mayer 2016). They remain and are maintained exactly as social forces necessitate them. The concept of the individual family clan, close kinship community to still feel responsible for the immediate security of a given family in most parts of Kurdistan, is a phenomenon that was kept alive by the historical challenges of Sykes-Picot, Sevres and Lausanne, the Kurdish Republic in Mahabad (McDowall 1996), the Barzanji and the Barzani Revolts, the Halabja genocide and the wider Baathist administered genocide against Kurds, the civil wars of the 1990s, and today's fight against ISIS, intermittently the PKK, and occasionally the Popular Mobilization units (Shia militias) that gathered around Mosul together with Kurdish Peshmerga in 2016-2017.

\section{Conclusions}

I thus argue that concepts such as historical experience (broadly understood), and on-going traditions of independent insurrection (that sees the young and married men of a family as warriors, especially in "tribal" rural areas but also in Kirkuk and even in "de-tribalized" Erbil), is relevant in situations of war, influencing even outcomes of wars occasionally in the region. Hence I talk about the historical nature of the stricter and more state-centric take on the concept of securitization and I offer a solution in the form of "semi-spontaneous securitization" in cases where the liberal democratic nation state does not exist and where more traditional 
forms of securitization result in not Hobbesian "state of nature" but on the contrary, a relatively lower level of threat for all. This is not in any way to label any social phenomenon, including the phenomenon of insurrectio or semi-spontaneous securitization, somehow pre-modern. On the contrary: it is to remedy the ahistorical shortcomings of the mainstream theory. Modernity itself, as post-colonialist thinkers such as Ramon Grosfoguel and Tejumola Olaniyan remind us, is inclusive not only of the widely defined centers of the world economy (and the political and economic structures reigning therein) but also the periphery (Grosfoguel 2011; Olaniyan 1993). If one feels that historically extant phenomena serve us well when understanding a current political, economic and social phenomenon, it is not in order to deny the modernity of the latter, but indeed to shed light on a segment of the modern, global present.

A related and indeed, relevant blind spot in Buzan, Waever and de Wilde, is the somewhat glib and nonchalant way they include immigration as something that may easily and "legitimately" be securitized where the referent object of securitization is the ethnic self-definition, social cohesion, religion, or a particular concept of the nation (Buzan \& Waever \& de Wilde 1998). "Societal security concerns the sustainability, within acceptable conditions for evolution, of traditional patterns of language, culture, religions and national identity and custom," the authors start the discussion (Buzan \& Waever \& de Wilde 1998). "In the societal sector, the analyst looks at the systems in terms of patterns of identity and the desire to maintain cultural independence," follows the point from the vantage point of the analyst (Buzan \& Waever \& de Wilde 1998).

In the end, rather startlingly:

"In the societal sector, as we have defined it, the referent object is large scale collective identities that can function independent of the state, such as nations and religions. Given the peculiar nature of this type of referent object, it is extremely difficult to establish hard boundaries that differentiate existential from lesser threats. Collective identities naturally evolve and change in response to internal and external developments. Such changes may be seen as invasive and heretical and their sources pointed to as existential threats, or they may be accepted as part of the evolution of identity. Given the conservative nature of "identity", it is always possible to paint challenges and threats to identity, because "we will no longer be us," no longer the way we were or the way we ought to be to be true to our "identity". Thus, whether migrants or rival identities are securitized depends upon whether the holders of the collective identity take a relatively closed-minded or a relatively open minded view of how their identity is constituted and maintained. The abilities to maintain and reproduce a language, a set of behavioral customs, or a conception of ethnic purity can all be cast in terms of survival." (Buzan \& Waever \& de Wilde 1998).

Unfortunately, when Buzan carries constructivist notions of securitization and the concept of the non-participant observer this far, we are confronted with a framework of theory that becomes deeply problematic. After all, there is no statement in the above passage that alludes to normative issues or the question of morality. In fact, as all is in the eye of the beholder, or more aptly, in the mind of the securitizing actor (enunciator) and his wider social audience that enables him to perform the security speech act, the securitizing actor may legitimately become a Hitler, a Stalin, a Tojo, or a Milosevic and the analyst does not blink an eye. A "relatively closedminded" electorate according to Buzan may compel or enable the actor to legitimately seal off borders or mercilessly let immigrants die at sea, or an inter-subjective perception of threat and securitizing move may well include gas chambers. There have been historians, such as Ernst Nolte, who argued seriously that Jews in the Third Reich were a fifth column and thus each and every securitizing speech act and course of action against them must logically have been in order, including but not limited to genocide.

Let us deconstruct Buzan's take in terms of its language. When Buzan simultaneously claims that "Collective identities naturally evolve and change in response to internal and external developments" (Buzan \& Waever \& de Wilde 1998) and also that "such changes may be seen as invasive and heretical and their sources pointed to as existential threats," he seems to defy logic. If "collective identities naturally evolve and change in response to internal and external developments" (italicization by A.M.) then the idea that exactly the same changes can be seen as invasive means that what was natural is now invasive: these two adjectives contradict each other. In fact, Buzan here seems to switch the vantage point of the analysis in between the two statements and what he, the external observer deems natural, seems or appears invasive for the participant. However, in a constructivist 
analysis, we should not see "God's eye's view" type statements such as this. When Buzan's text deems a change natural, he must mean this inter-subjectively, notably representing and including the view of the affected parties: in any other case he is nothing but a positivist thinker. However, if an affected party considers a change invasive, she cannot, by definition, look at the same phenomenon as natural. It is here that one is drawn to believe Buzan could have mentioned how electorates are manipulated by populist political actors who intend to twist and corrupt the views of their political constituencies and turn them to ethnicist, exclusivist solutions. I definitely consider Buzan's omission of the misuses of identity centered discourse here significant.

Mercifully, Buzan later chose not include a discussion of immigration as a legitimate referent object of securitization. In his 2009 grand re-evaluation of the sub-discipline that he had launched, he skips any discussion on the subject (Busan \& Hansen 2009). This is an especially welcome development when it comes to applying theory to our case study of ISIS and the Kurds. ISIS has a uniquely exclusivist conception of who should constitute the ummah, and thus how and when migration and immigration should be securitized. The forced emigration of Christians and others (even with the choice of an exorbitant, unsustainable jizye) from under ISIS rule could be looked at as an example of unfortunate but legitimate securitization if we took Buzan's conception of societal security at face value. It would also be extremely bizarre to discuss this in relation to an ethnic and national group, the Kurds that suffered chemical gas attacks during Saddam Hussein's Anfal campaign in the late 1980s. Thirdly, when it comes to the situation of 'societal security' as Buzan presents it, the treatment of IDPs from Mosul and its environs, would be affected in a terrible way, were the leadership of the Kurdistan Regional Government to consider Buzan's inhuman option of societal exclusion even a possibility.

This will affect the way how the crucial Article 140 of Iraq's Constitution, concerning the status of Kirkuk Governorate and other adjacent territories, would in future be carried out. As the relatively early stage of Saddam Hussein's Anfal campaign, the Governorate of Kirkuk and also of Mosul were forcibly Arabized in their ethnic composition from the 1970s onwards, up to 1991. Article 140 stipulates that referenda should be held on the eventual status of these regions (Bartu 2010) but that the Arabization moves of the Anfal campaign and its human rights effects on the original Kurdish population should also be remedied and addressed before such referenda and appropriate censuses are organized. Naturally, along with the question of IDPs and their immediate needs, the issues connected with Article 140 (along with the international community, NGOs, intergovernmental organization, the human rights community, and even philosophical and mainstream religious conceptions of compassion and humanity) all urge the KRG to exercise self-restraint and in the face of IDP screening challenges and legal obstacles, when dealing with Sunni Arab and Shia Arab immigration and presence in KRG administered areas. Arguably, the livelihoods of many people, along with prospects for "deep conflict resolution" will depend on how the KRG manages to balance these considerations. A precondition of this is that the political leadership should not consider Buzan's glibly termed "relatively closed-minded option" a possibility.

It is only prudent to note here that I am not the first to comment critically and point out dangerous ideatic liaisons between dubious ideology and Buzan's theoretical framework. In “Inhuman Security”, Mark Neocleous uncovers a number of ways in which Buzanian constructivism is heavily indebted to Carl Schmitt. The ISS speech act's enunciator according to Neocleous is similar to Schmitt's famous 'sovereign' who decides on the exception and tells friend from foe (Neocleous 2011). It would be difficult to debate Neocleous's criticism especially given the author's sensitivity to the possible dangers inherent in marshaling security for the purpose of new and virulent versions of exclusion today in Europe and elsewhere. Through the above analysis, I also see an opportunity for historical methods to temper the potentially dangerous aspects of constructivist security theory in Iraq as well as in Europe. Other than this, I propose a rethinking of Buzanian concepts of securitization in general, especially in African, MENA, and West Asian contexts. Isurrectio and spontaneous and semi-spontaneous securitization has arguably been relevant to places as diverse as Western Sahara, the larger Sahel, Sudan, the Horn of Africa, Transylvania, historical Hungary, Kurdistan, and Arabia. Spontaneous taking up of arms without a clear enunciation that defines the Buzanian understanding of threat ends up diluting the philosophical generalization that defines Buzanian universal categories. Buzan's enunciator and speech act are thus relevant in unitary, modern nation states with borders and centralized armies. But as since the 1990s, many locales in the world are becoming less and less easily territorially defined and less strictly unified in the 
organizational sense, it is time to on the one hand conduct extensive studies of the cases of insurrection as opposed to the Buzanian speech act from Western Sahara to Somalia historically and today, and on the other hand, expand and deconstruct Buzanian logic as more suited to only some situations as opposed to being a universally valid "God's eye view" type Western kind of theory. This way we allow Buzanian frameworks to operate in a more truthful and more relevant manner with cases where they really are applicable.

\section{References}

Agoston, G. 1992. A hodolt Magyarorszag ('Ottoman Hungary', in Hungarian). Adams Kft.

Amarilyo, E. 2014. The Dual Relationship Between Kurdish Tribalism and Nationalism. 63-82, in Bengio, O. (Ed.). Kurdish Awakening: Nation Building in a Fragmented Homeland. University of Texas Press.

Barkey, K. 2008. Empire of Difference: The Ottomans in Comparative Perspective. Cambridge University Press.

Bartu, P. 2010. Wrestling with the Integrity of a Nation: The Disputed International Boundaries in Iraq. International Affairs, 86 (6): 1329-1343. https://doi.org/10.1111/j.1468-2346.2010.00946.x.

Besenyő János, Prantner Zoltán, Speidl Bianka, Vogel Dávid 2016. Az Iszlám Állam - Terrorizmus 2.0 Kossuth Kiadó

Buzan, B.; Hansen, L. 2009. The Evolution of International Security Studies. Cambridge University Press.

Buzan, B.; Lawson, G. 2015. The Global Transformation: History, Modernity, and the Making of International Relations. Cambridge University Press.

Buzan, B.; Waewer, O.; De Wilde, J. 1998. Security: A New Framework for Analysis. Cambridge University Press.

Cockburn, P. 2015. The Rise of Islamic State: ISIS and the New Sunni Revolution. Verso.

Dalshad, A. 11 August 2014. Arms trade flourishes in Erbil as fears of ISIS grow. Asharq Al-Sawsat. Retrieved from: http://english. aawsat.com/2014/08/article55335319/arms-trade-flourishes-in-erbil-as-fears-of-isis-grow

Dunn, S. P. 2012. The Fall and Rise of the Asiatic Mode of Production. Routledge Revivals.

Eddelani, O.; El Amrani El Idrissi, N.; Monni, S. 2019. Territorialized forms of production in Morocco: provisional assessment for an own model in gestation, Insights into Regional Development 1(1): 6-18. http://doi.org/10.9770/IRD.2019.1.1(1)

Eppel, M. 2014. The roots of modern Kurdish nationalism. Bengio, O. (Ed.). Kurdish Awakening: Nation Building in a Fragmented Homeland. University of Texas Press.

Forman, M 1998. Nationalism and the International Labour Movement: The Idea of the Nation in Socialist and Anarchist Theory. Pennsylvania State University Press.

Gat, A. 2012. Nations: The Long History and Deep Roots of Political Ethnicity and Nationalism. Cambridge University Press.

Grosfoguel, R. 2011. Decolonizing Post-Colonial Studies and Paradigms of Political-Economy: Transmodernity, Decolonial Thinking, and Global Coloniality. TRANSMODERNITY: Journal of Peripheral Cultural Production of the Luso-Hispanic World, 1 (1): 1-37. https://www.escholarship.org.uc/item/21K6t3fg

Gunther, M. M. 2004. Historical Dictionary of the Kurds. The Scarecrow Press.

Hanieh, A. H.; Abu Rumman, M. (2015): The "Islamic State” Organization: The Sunni Crisis and the Struggle of Global Jihadism. Friedrich Ebert Stiftung.

Hobsbawm, E. 1992. Nations and Nationalism since 1780: Programme, Myth, Reality. Published by Cambridge University Press (2nd Edition).

House of Commons Library. 19 March 2015. ISIS and the Sectarian Conflict in the Middle East. Research Paper 16 (15): 5-9.

Howard, D. A. 2017. A History of the Ottoman Empire. Cambridge University Press.

Inalcik, H. 1973. The Ottoman Empire: The Classical Age 1300 - 1600. Weidenfeld \& Nicolson. 
Limba T.; Agafonov K.; Paukštè L.; Damkus M.; Plèta T., 2017. Peculiarities of cyber security management in the process of internet voting implementation, Entrepreneurship and Sustainability Issues 5(2): 368-402. http://doi.org/10.9770/jesi.2017.5.2(15)

Lisin, E.; Kurdiukova, G.; Ketoeva, N., Katina, J. 2018. Sustainability issues of territorial power systems in market conditions, Entrepreneurship and Sustainability Issues 6(2): 1041-1052. http://doi.org/10.9770/jesi.2018.6.2(38)

Mayer, A. 2016. Afrikanizacija: Eastern European Epistemologies and African Labour. Intersections. East European Journal of Society and Politics, 1 (2): 58-60. Retrieved from: http://intersections.tk.mta.hu/index.php/intersections/article/view/135. https://doi. org/10.17356/ieejsp.v2i1.135

Mayer, A. 2016. Naija Marxisms: Revolutionary Thought in Nigeria. Pluto Press. 12.

Mayer, A. 2018. Ifeoma Okoye: socialist-feminist political horizons in Nigerian literature. Review of African Political Economy, 45 (156): 338-339. Retrieved from: https://www.tandfonline.com/doi/abs/10.1080/03056244.2018.1482827

Mcdowall, D. 1996. A Modern History of the Kurds. I.B. Tauris.

Mikhaylov, A.S.; Mikhaylova A.A.; Savchina, O.V. 2018. Innovation security of cross-border innovative milieus, Entrepreneurship and Sustainability Issues 6(2): 754-766. http://doi.org/10.9770/jesi.2018.6.2(19)

Misri, A. 2 December 2014. Hundreds volunteer to boost Peshmerga morale. Rudaw on line. Retrieved from: http://www.rudaw.net/ english/kurdistan/021220141

Natali, D. 2010. The Kurdish Quasi-State: Development and Dependency in Post-Gulf War Iraq. Syracuse University Press.

Neocleus, M. Inhuman Security, in: Chandler, D; Haynek, N. 2011. Critical Perspectives on Human Security: Rethinking Emancipation and Power in International relations. Routledge.

Olaniyan, T. 1993 Autumn. On "Post-Colonial Discourse": A Special Issue. Introduction. Callaloo 16(4): 743-749.

Romano, D. 2006. The Kurdish Nationalist Movement: Opportunity, Mobilization, and Identity. Cambridge University Press. 171.

Sawer, M. 1977/2013. Marxism and the Question of the Asiatic Mode of Production. Springer.

Spivak, G. Ch. 2010. Nationalism and the Imagination. Seagull.

Strange, S. 1988. States and Markets. Pinter.

Tvaronavičienè, M. 2018. Towards internationally tuned approach towards critical infrastructure protection, Journal of Security and Sustainability Issues 8(2): 143-150. https://doi.org/10.9770/jssi.2018.8.2(2)

Vuori, J. A. 2011. How to Do Security with Words: A Grammar of Securitization in the People's Republic of China. University of Turku Press.

\section{Author:}

Dr. habil. János BESENYÖ Ph.D., Colonel, Head of Department: HDF General Staff Scientific Research Centre, H-1885 Budapest, Pf.25, Hungary 